\title{
From Spirituality to Responsible Leadership: Ignatian Discernment and Theory-U
}

\author{
Patrick Nullens
}

\begin{abstract}
In its desire to build a bridge between self-awareness and morally responsible leadership, this chapter seeks to contribute to the theory of authentic leadership. The central thesis of this chapter is that Ignatian spiritual discernment is a valuable resource for making this connection. Ignatian Spirituality is directed at the world, the world beyond the self and the world beyond our primary experiences. It is inherently aimed at the common good and is therefore an interesting source when contemplating moral leadership. We will discuss the Spiritual Exercises of humility, silence, and detachment, the prevalence of emotions and imagination, ethical evaluation, and journaling and mentoring as means for increasing self-awareness. We will do this in dialogue with the new Theory-U. This, too, is an approach where societal meaning is fundamental and seeks to increase awareness and genuine openness to the future by letting go of the self. This makes for an interesting dialogue, leading to a deeper understanding of spiritual discernment.
\end{abstract}

\section{Ignatian Spiritual Discernment and Addressing Our Blind Spot}

The volatility, uncertainty, complexity, and ambiguity (VUCA) we are faced with in today's world demand that we make fast decisions and to get it right. In this highly competitive world, there is no room for trial and error, nor will we get a second chance. In plain language the managerial acronym VUCA means "Hey, it's crazy out there!" (Bennett and Lemoine 2014). It describes the sense that, even with all our technological power, we are not in control and the future is unpredictable. VUCA can also mean: "Hey, it's crazy in my head!" Volatility, uncertainty, complexity, and ambiguity are not only to be found in the world around us, they also become the

\footnotetext{
P. Nullens $(\bowtie)$

Evangelische Theologische Faculteit, Leuven, Belgium

North-West University, Potchefstroom, South Africa

e-mail: patrick.nullens@etf.edu
} 
storms within us. In this turbulence, we feel a need for a space where time stands still and where we can experience the present. How do we calm our internal storms? How do we make mental space for discernment when it comes to strategic life decisions? The greatest challenge is not the process of quieting our minds and becoming more mindful in body, thinking, and emotions; even more challenging when it comes to leadership is to create a deeper awareness that results in making the right decision to the benefit of others. What we desperately need is a form of authentic leadership, resulting from deeper awareness and from addressing the blind spot, the inner source from which we act (Scharmer 2016, p. 22). Authenticity requires rootedness in ourselves, in our story, and in our faith traditions.

This chapter hopes to contribute to the authentic leadership theory, one of the newest areas of leadership research which makes ethics the center of leadership (Hannah et al. 2011; George et al. 2015). ${ }^{1}$ According to Avolio, its central premise is "that through increased self-awareness, self-regulation, and positive modeling, authentic leaders foster the development of authenticity in followers. In turn, followers' authenticity contributes to their wellbeing and the attainment of sustainable and veritable performance" (Avolio and Luthans 2005, p. 317). There are many ways to create this bridge between a deeper self-awareness and morally responsible leadership. As one optional pathway, we'll look at the Ignatian model of spiritual discernment. This chapter focusses on the individualistic aspect of Ignatian discernment. The interaction between leadership theory and Ignatian spirituality is of course not new (Moberg and Calkins 2001; Darmanin 2005; Rothausen 2017). There is also an increased interest in different kinds of spiritual discernment. The dialogue between Ignatian and secular forms of discernment, however, does remain largely unexplored (Bouckaert 2017, p. 16). Referring to Ignatius's Spiritual Exercises (Sp.Ex.), Moberg and Calkins have pleaded for more room for reflection, and not just decision making, in the curriculum of business schools . Reflection means bending back on oneself, allowing more space for emotions and the imagination (2001, p. 258).

At the outset of our quest, we'll observe the growing appreciation of spiritual intelligence, spiritual vitality, and workplace spirituality. This new research interest within the social sciences makes way for more spiritual approaches to decision making in leadership. A broad leadership model that can relate easily to this new quest is Theory-U (Scharmer 2016). In the second part of this chapter I will present Theory-U in broad brushstrokes. The chapter pleads for a Christian approach, more specifically the Ignatian way of discernment as it might be helpful for making decisions. This is the central thesis of this chapter, and its main focus. The argument is not theological ${ }^{2}$ nor apologetic, as if this were the only true and valid model, but

\footnotetext{
${ }^{1}$ Four behavioral components are crucial to this theory: self-awareness, internalized moral perspective, balanced processing, and relational transparency (Northouse 2016, pp. 193-223).

${ }^{2}$ In this essay I haven't opted for a critical theological engagement. The publications on this specific topic of comparative spirituality are limited (Richter 1955; Lafontaine 2011). For instance, the comparison between Ignatius and the Calvinist puritan Richard Baxter on meditation is interesting (Hinson 2007). It is a myth that the Jesuits were established to fight the reformation. This was a later development, which occurred after Ignatius (see Maryks 2014). More practically, there are also
} 
rather that it is a reliable method that has been tested over many hundreds of years. Discernment is an implicit part of Christian spirituality-it is clearly present in the writing of St Paul. However, there are relatively few explicit instructions on discernment. By far the most accessible and comprehensive of these systems is that found in the Spiritual Exercises. However, I am aware that some readers might prefer a more generic form of spiritual discernment, not grounded in a particular religious tradition. In my opinion, the main problem here is the common but deceitful disconnection of spirituality and religion that often functions as a secular dogmatic presupposition. It suggests that being rooted in one particular religious tradition, be it Christian, Jewish, or Muslim, diminishes mental openness and our capacity for discernment. In the third paragraph I make a case for the re-connection of faith and spirituality, which have been artificially separated. In the three sections that follow, I try to establish Ignatian discernment as a valid form of Christian discernment in leadership. To a limited extent, I will make some connections with Scharmer's Theory-U. In Theory-U, societal meaning is obviously robust. It is my contention that the theological particularity and Christian character of the Ignatian model does not negate this broader impact. It is the interesting dialogue between the new and the old which leads to a deeper understanding of spiritual discernment as an intrinsic part of authentic leadership.

\section{Spiritual Intelligence and Discernment}

At the beginning of the twenty-first century the spiritual dimension of leadership is widely recognized (Fry 2003; Fry and Nisiewicz 2013; Scharmer 2016; Dhiman 2017). According to some scholars, the successful transformational leadership theory was all too limited to the service of institutional practices and goals and weak in core values and service to the common good (Rothausen 2017, p. 7). In addition to the concept of "emotional intelligence," which came to the fore near the end of the twentieth century (Goleman 2014) and which underpins the transformational leadership theory, the concept of "spiritual intelligence" (SI or SQ) appears on the horizon of our postmodern age (Zohar and Marshall 2001; Wigglesworth 2014; Dhiman 2017). SI is the intelligence of our inner source, our true self, our transcendental capacities. As one might expect, a plethora of definitions circulate. A broad working definition is:

Spiritual intelligence is concerned with the inner life of mind and spirit and its relationship to being in the world. Spiritual intelligence can be defined as the ability to create meaning based on deep understanding of existential questions, and awareness of and the ability to use multiple levels of consciousness in problem solving. (Vaughan 2002, p. 30).

protestant-evangelical books appropriating the Spiritual Exercises (Wakefield 2006; Warner 2010). However, this doesn't mean there are some serious points of difference, for instance the call for radical obedience to the Roman Catholic church in the Spiritual Exercises (pp. 353, 358, 365 etc.) is highly problematic for a protestant Christian, including the author of this chapter. 
In popular leadership theory SI is appropriated by Stephen Covey. In his recent 8th Habit, Covey mentions four types of intelligence: Physical intelligence (PQ), which corresponds with the body; mental intelligence (IQ) corresponds to the mind; emotional intelligence (EQ) corresponds to the heart and finally there is spiritual intelligence (SQ), which is connected to the spirit. Spiritual intelligence is our drive for meaning and connection with the infinite. According to Covey "spiritual intelligence is the central and most fundamental of all the intelligences, because it becomes the source of guidance for the others" (Covey 2014, p. 53).

The organizational value of spiritual intelligence is well documented. For instance, Laura Reaves has reviewed 150 studies showing the clear consistency between spiritual values and practices and effective leadership. According to Reave, spirituality helps leaders to inspire trust, motivate followers, create a positive ethical and relational climate, and achieve organizational goals. The impact of spirituality is not only present in this soft area, it also increases productivity, lowers rates of turnover, and improves employee health and sustainable development (Reave 2005). In this chapter we focus on just one aspect of this spiritual dimension: the reflective practice which includes self-examination and/or communication with God. This is a practice that increases managerial effectiveness. Spiritual vitality is a strength for managers since it gives them a more global view of life and makes them less dependent on current situations (Quick et al. 2000).

Along with the appreciation of spiritual intelligence there is a growing interest in “workplace spirituality" (Neal 2012; Giacalone and Jurkiewicz 2015). Employees are looking for meaning in their jobs. Yet again, definitions vary widely. A possible working definition for workplace spirituality is:

... aspects of the workplace, either in the individual, the group, or the organization, that promote feelings of satisfaction through transcendence. To elaborate, that the process of work facilitates employees' sense of being connected to a nonphysical force beyond themselves that provides feelings of completeness and joy (Giacalone and Jurkiewicz 2015, p. 15).

Jody Fry deals with spiritual leadership as a moral source in the business world. His model of spiritual leadership is based on vision, altruistic love, hope/faith, and intrinsic motivation (Fry 2003). According to Fry, values such as trust, the value of human life, and altruistic love are found in the major world religions as well as in secular models. The ethical call of the triple bottom line of a company is coupled with spiritual leadership, which creates a vision and organizational culture that transcends egoistic self-interest and fosters a value-driven stakeholder approach (Fry and Nisiewicz 2013). According to Fry, a sustainable economy requires a spiritual approach through which we can overcome our desires for short term profits.

The quest for joy, completeness, and wellbeing typical of the Western stressful and fast-changing world, leads to renewed interest in meditation and inner resourcing. The success of mindfulness as a method for stress reduction, shows the present need for space, time, and internal rest (Chiesa and Serretti 2009). The young science of positive psychology values spirituality as part of a healthy life, as it strengthens our agency and daily functionality. "The capacity to envision, seek, 
connect to and hold on to, and transform the sacred may be what makes us uniquely human" (Pargament and Mahoney 2011, p. 616). There is a noticeable sociological and demographic shift from materialist to post-materialist societal values: an increased desire for fulfillment, freedom, a sense of community, self-expression, and meaning. It is expected that, globally, post-materialists emphasizing selfexpression values will soon outnumber materialists; organizations and businesses need to take this new reality into account (Inglehart 1997; Inglehart and Welzel 2005; Giacalone and Jurkiewicz 2015).

The practice of discernment in order to make the best decision about the future of an organization, one's career, or new opportunities goes beyond the classical cognitive social and emotional processes. This is evidenced by the rising interest in spiritual intelligence, workplace spirituality, the search for meaning, and stress reduction. A deeper awareness and a sense of the future are vital to making the right decisions. This in turn raises a renewed interest in the Ignatian method of discernment as well as some newer models, generally rooted in Eastern philosophy.

\section{Theory-U and Leadership Spirituality}

In light of the broad shift towards more awareness and post-materialist societal values, Theory- $U$ is a notable model, especially because of the paradigmatic changes it proposes. Theory-U was developed by C. Otto Scharmer at the Massachusetts Institute of Technology. It found its way to management, health care, education, economics, and organizational sciences. ${ }^{3}$ We are confronted with some serious global challenges, such as climate change, poverty, violence, and the income gap. It is essential for Theory-U that our complex problems need solutions that do not come from the old paradigms that created them in the first place. Scharmer makes a call for a new consciousness and a fresh approach to leadership.

According to Scharmer, we often observe the behavior of leaders, the strategies and processes they deploy. But there also seems to be a blind spot, blindness to the inner place, the source from which leaders act and from which effective leadership and social action come into being (Scharmer 2016, p. 21). And what is true for individual leaders is also true for groups and society: "Blind spots appear in individuals, groups, institutions, societies, and systems; they reveal themselves in our theories and concepts in the form of deep epistemological and ontological assumptions." (Scharmer 2016, p. 21) The attention of Theory-U goes to the inner center of our being as essential for leadership; what really counts is where you're coming from, inside your deepest being: "the success of an intervention depends on the interior condition of the intervener." (Scharmer 2016, p. 27) It is the inner place of the leader, mysterious as it is, that ultimately defines the outcome. Scharmer is convinced that we have to work and train more inside-out. What is required is a shift

\footnotetext{
${ }^{3}$ See www.presencing.org
} 
in consciousness from ego-system to eco-system awareness (Scharmer and Kaufer 2013).

Most of our knowledge is a result of a superficial "downloading," instead of a careful experience of a future as it emerges. Scharmer proposes a learning theory in the form of a "U," based on the attitudinal stages of letting go, "presencing," and letting come. ${ }^{4}$ The neologism "presencing" is a blending of the words "presence" and "sensing." "It means to sense, tune in, and act from one's highest future potential - the future that depends on us to bring it into being." (Scharmer 2016, p. 8) More concretely, presencing is a journey with five movements or a matrix of five dimensions: We move down the left side of the $\mathrm{U}$, all the while connecting to the world that is outside of our well known structures. Reaching the bottom of the $U$ we connect to the world that emerges from within. And as we move up on the right side of the U, we've reached the "letting come": embodying and bringing forth the new into the world. The movement of the U shouldn't be seen as linear stages, but as dimensions or a matrix of perceiving reality. It is a dance with the situation you are dealing with (Scharmer 2016, pp. 44, 45).

On that journey, at the bottom of the $\mathrm{U}$, lies an inner gate that requires us to drop everything that isn't essential. This process of letting go (of our old ego and self) and letting come (of our highest future possibility: our Self) establishes a subtle connection to a deeper source of knowing. The essence of presencing is that these two selves, our current self and our best future self, meet at the bottom of the $U$ and begin to listen to and resonate with each other. The task of discernment is to catch the future as it comes to us. There is a process of an open mind, an open heart and an open will. Retreating and letting go for a time of reflection becomes the basis for later action. Once an individual or a group crosses this threshold, nothing remains the same. People begin to operate with a heightened level of energy and increased sense of future possibility. Often, they then begin to function as an intentional vehicle for an emerging future.

\section{Spirituality and Religion Connected}

Before we enter the religious world of Ignatian spirituality, a word needs to be said about the relationship between spirituality and religion. Scharmer is critical of "a faith-based spirituality," since it can mean a conservative retro-movement and even fundamentalism (Scharmer 2016, p. 4). ${ }^{5}$ Being oriented by a faith system is the very opposite of being open to the future. For Scharmer, there is barely space for religion at all. ${ }^{6}$ And as is often

\footnotetext{
${ }^{4}$ For figures see www.prescencing.com

${ }^{5}$ Scharmer describes fundamentalism as a particular form of "absencing," opposite of "presencing." He briefly discusses three forms of fundamentalism: religious, economic, and political (Scharmer 2016, pp. 244-245).

${ }^{6}$ His main intellectual sources are Buddhism, Rudolf Steiner, Edmund Husserl, Martin Buber, Martin Heidegger, Jurgen Habermas, Johan Galtung, Friederich Glasl, Francisco Varela (p. 104).
} 
the case, spirituality is disconnected from religion, as if we are dealing with some Kantian universal scientific model that stands above all particularities of ideals and religions.

It is often argued that throwing spirituality into the mix adds up to uncertainty and ambiguity. But in fact, it can go both ways, as is the case with religion: it may obscure the functioning of some people, but it makes others more effective. The distinction between religion and spirituality is widely accepted. Generally speaking, religion refers to the external dimension such as institutions, dogma, practices, symbols. Spirituality on the other hand, refers to the inner life, the subjective, experiential, and emotional dimension.

In psychological terms, spirituality is broadly described as something that gives meaning to life and the experience of being part of a larger whole. For instance, Sandra Schneiders defines: "Spirituality is the actualization of the basic human capacity for transcendence . . . defined . . . as the experience of conscious involvement in the project of life-integration through self-transcendence toward the horizon of ultimate value one perceives" (in Holder 2005, p. 16). From this point of view, spiritual discernment is mainly about life-integration and reconnecting to one's own value system. Such a broad interpretation may lead to the conclusion that faith systems are redundant.

In contrast, we opt for an integration of spirituality and lived religion. While both terms are useful in order to distinguish between the subjective and objective dimension, the two cannot be disconnected from one another. Kees Waaijman rightfully critiques the quasi-dogmatic separation between spirituality and religion that dominates the social sciences. He states that by the disconnection from the original philosophical-theological perspective on spirituality, the conceptual depth of spirituality gets lost (Waaijman 2007, p. 88). If religion is a lived religion it integrates conceptual views of faith (as content) and spiritual experiences. ${ }^{7}$ Particularly when faced with the challenge of discernment, conceptual framing, a concrete religious community, a faith tradition, and textual sources all play a significant role. Moreover, this religious framing is not a limitation, it is a concretization or manifestation of spirituality.

In the same way, Kenneth Pargament defines spirituality as "the search for the sacred" (Pargament and Mahoney 2011, p. 612). The term "search" indicates that spirituality is always a process, "one that involves efforts to discover the sacred, hold on to the sacred once it has been found, and transform the sacred when necessary" (Pargament and Mahoney 2011, p. 612). The sacred is a broad term, which could be interpreted theistically or as a transcending ideal that we experience as sacral. ${ }^{8}$

\footnotetext{
${ }^{7}$ In theology we distinguish fides qua, our act of believing, from fides quae creditor, the content of this belief. The two cannot be separated.

${ }^{8}$ For the idea of "the Holy" or the numinous we can also refer here to Rudolf Otto's classical Das Heilige (1917 [ET:1959]). The sacred is irreducible, a manifestation of the "ganz Andere." [The "ganz Andere" is a (famous) way in which Barth describes God-it is not, however, how Otto conceptualized "das Heilige" (note his use of "das" instead of "der"): for Otto, "das Heilige" is the "numinous," not necessarily a personal conception of a God/gods.
} 
Equally important is the realization that there are many potential pathways for this life-search. To put it metaphorically: spirituality provides the paint, brushes, and a canvas, but lived religion draws the picture, diverse as it might be. Whether we consider the picture to be a piece of art or rubbish, is another question. This is where the theological argument will take place. Moreover, Waaijman points out, experiences in and of themselves are blind and need critical feedback from an ethical perspective. Therefore, spirituality is not only connected to a faith system, but also to a specific configuration of virtues or character (Waaijman 2007, p. 6). The focus of this chapter is Christian spirituality that Holmes defines briefly as "the lived experience of Christian faith and discipleship" (Holder 2005, p. 5). As a concrete type of "lived experience" it is a form of spirituality, and therefore it is profitable to connect with broader studies of spirituality from other disciplines, such as, for instance, Theory-U. As a lived experience it has its own language and traditions. So whereas in the broader context one may bring in new words such as "presencing," with the lived experience of Christianity one picks up the old language of faith. Johan Verstraeten sees this openness to different language as a prerequisite for true moral reflection on one's business practice. We don't use the common managerial vocabulary of control, efficiency, institutions, and measurement, but a language of meaning, metaphors, and narratives (Verstraeten 2014).

\section{The Spiritual Exercises of Ignatius of Loyola}

Ignatius of Loyola (1491-1556), the founder of the Societas Jesu (1539) is the subject of much debate, and the heritage of the Jesuits is not without blemish. This chapter is not the place for a hagiography, not even a biography. ${ }^{9}$ But, however briefly, we need some facts to put his new approach to spirituality in context. Ignatius (Iñigo) was a military officer of noble birth. His family was from the Basque region, in the north of Spain. In his youth, he is described as a vain person, living the worldly lifestyle of a nobleman, obsessed by heroic stories. In a losing battle against the French, he was hit in the knee by a cannonball. During his long recovery Iñigo read books about the life of Jesus and the lives of the saints. This was the beginning of his "search for the sacred," a long and intense journey. These experiences were the basis of a short handbook for meditations written in Spanish, entitled Spiritual Exercises (1522-24). ${ }^{10}$ Ignatius began to share his spiritual principles because he believed the exercises could also help others and the Spiritual Exercises have become fundamental for the Society of Jesus and far beyond.

\footnotetext{
${ }^{9}$ A classic biography is the one by Philip Caraman (1990). A well-documented biography written from a psychoanalytic lens is the one by W. Meissner (1994).

${ }^{10}$ Most of the Spanish text was finished by 1541 . With papal approval, a Latin translation was published in 1548. In this article the 1951 translation of Louis J. Puhl is used, available at http:// spex.ignatianspirituality.com/SpiritualExercises/Puhl\#pre01. Accessed 15 January 2018.
} 
For a good understanding of the Spiritual Exercises (Sp.Ex.) we need to read them against the background of Ignatius's wider corpus of texts, for instance his Constitutions, Autobiography and Spiritual Diary (Ignatius et al. 1997). Equally important are his many letters (about 7000) containing pastoral and practical advice (Ignatius et al. 2006). The Sp.Ex. are a particular literary genre consisting of a compilation of prayers, meditations, and contemplative practices, intended to help people deepen their relationship with God. In style it is brief, with dense wording, sometimes even cryptic. The Spiritual Exercises are not meant as a devotional book for a wide public, rather they are written as a handbook for spiritual directors to use in the context of a 4-week (30 days) or shorter ( 8 days) retreat in solitude and silence. The purpose of all spiritual exercises is an examination of conscience and a training in spiritual discernment (discretio), the discernment of good from evil spirits. The Sp.Ex. combine three interconnected elements: first, praying with the gospel texts, a focus (visualization) on the life of Jesus; second, an intense examination of one's own conscience and finally, as a form of synthesis, to discern and come to a spiritual decision. Its purpose is the pedagogy of the best choice, wherein the higher greater glory of God is always the ultimate purpose. It is really a practical handbook for exercises, not just devotional writing to be read and meditated on. In the opening words of Ignatius himself:

By the term "Spiritual Exercises" is meant every method of examination of conscience, of meditation, of contemplation, of vocal and mental prayer, and of other spiritual activities that will be mentioned later. For just as taking a walk, journeying on foot, and running are bodily exercises, so we call Spiritual Exercises every way of preparing and disposing the soul to rid itself of all inordinate attachments, and, after their removal, of seeking and finding the will of God in the disposition of our life for the salvation of our soul. (Sp.Ex. 1.)

To use the terminology of Theory- $\mathrm{U}$, a continued training is required to overcome superficial listening (downloading), suspend judgment, abandon cynicism and fear and to go to generative listening. It is not a onetime event, but a training; repetitive exercises that lead to a change of habits. Theory-U, much like Ignatian spirituality, qualifies as a leadership development practice in the sense of "a coherent set of activities that is intentionally and regularly enacted by an individual" (Rothausen 2017, p. 4).

\section{Ignatian Spirituality for the World and Beyond the World}

The art of discernment and decision making is only part of an overall spiritual formation, so it is important to understand how the decision-making process fits into the wider context of a practical spirituality. The Jesuit priest James Martin wrote a popular book, playfully entitled: The Jesuit Guide to (almost) Everything (2010). Martin summarizes four essential characteristics of Ignatian Spirituality:

1. Finding God in all things

2. Becoming a contemplative in action

3. Looking at the world in an incarnational way 


\section{Seeking freedom and detachment}

These four concepts are a faith-based approach that does not close off our experience of the world around us, but rather the supports opening up to one's surroundings. Finding God in all things and experiencing the world as a manifestation of God makes us sensitive to the meaning of little events around us. An important corrective on Martin's otherwise apt summary, is that they all take shape with Christ in the center. Christ himself is the norm of all discernment. Experiencing God's unconditional love in Christ, the power of the cross, reconciliation, and Christ's healing, and the resulting desire to be his disciple, is the main topic of the first week of Spiritual Exercises.

An important characteristic of Ignatian spirituality, especially in comparison with other traditions, such as for instance the Benedictine tradition, is that Jesuit spirituality is oriented towards the world outside the walls of the cloister. Here we see a similarity with the strong moral component of Theory-U, which wants to lead us out of ego-system into eco-system economics, a shift from wellbeing of the individual to the wellbeing of the whole. Spirituality is connected with contemporary challenges in economics, politics, and society (Scharmer and Kaufer 2013). Ignatian spirituality is missional: inner growth must lead to a change in society. Only limited attention is paid to contemplation: Jesuits are traditionally socially oriented and devoted to the promotion of the common good. The disengagement from society the Spiritual Exercises create, allows for a greater engagement with the self and with God. Its ultimate purpose is to enable better functioning in society. The adage "finding God in all things" makes Ignatian spirituality a way of living in the world. Martin summarizes it this way: "Instead of seeing the spiritual life as one that can exist only if it is enclosed by the walls of a monastery, Ignatius asks you to see the world as your monastery" $(2010$, loc. 165,166$)$. There is a deep commitment to advocating justice and the common good, and caring for the vulnerable (O'Brien 2011, p. 4). It is also called a "frontier spirituality," for those who want to be active on those risky frontiers where the church meets our secular and pluralistic world (Heiding 2012, p. 150).

Next to this immanent focus of Ignatian spirituality, there is also a transcendental side, the other-worldly dimension, the beyond. But first of all discernment is focused on the "movements of spirits" where "spirits" have a very broad meaning. Discernment is a form of interpreting what Ignatius calls "motions of the soul." These interior movements consist of desires, feelings, thoughts, imaginings, emotions, repulsions, and attractions. Discernment of spirits involves becoming sensitive to these mental movements, meditating on them, and understanding their sources and purposes. Spirits can include the Holy Spirit and the enemy of our human nature, but also includes the pulls from other interior and exterior impulses. Actually there is in this profundity or beyond no clear divide between natural and supernatural.

In a Christian faith system, this "beyond" is not merely an emerging future or a broad connecting with the planet, it is also, but not only, a supra-natural reality that is 
knowable beyond our natural senses. ${ }^{11}$ It sounds strange to most contemporary readers to hear about the continuous battle between that which comes from God and what comes from "the enemy." Of course, this metaphor of a battle fits well with Ignatius's former interest in the military, but the duality between God and devil is also deeply rooted in the New Testament worldview. ${ }^{12}$ According to the New Testament the world is dual, a world of matter and spirit, and that which is unseen is nevertheless real (Bonnie Thurston in Holder 2005, p. 56). For many Christians this is a very real conflict between two personal entities. Yet in a secularized worldview, for those living in a scientific and disenchanted world, this open view on transcendent reality is bizarre. For those, this spiritual battle can be explained as the continuous conflict between good and evil in one's personal self. However, this is merely one dimension of discernment. In most cases it is simply about discerning the good from the best in the motions of the soul.

Creating in a leader a moral center that goes beyond institutional goals is one of the major challenges we face today and requires more than a company list of core values, desired behaviors, and norms (Rothausen 2017). Scharmer regularly refers to Aristotle's Nicomachean Ethics and the five different ways of knowledge. First is science (episteme), exact knowledge determined by necessity, limited to the things that cannot be otherwise than they are. The other four ways of grasping truth are broader and apply to all other contexts of reality and life. They are art or creating (techne), practical wisdom (phronesis), theoretical wisdom (sophia), and intuition or the capacity to grasp first principles or sources (nous). It is by developing the sophia and nous that we overcome our obsession with the what (episteme) and how (techne). "It is that blind spot that sets apart master practitioners and leaders from average performers" (Scharmer 2016, p. 16).

\section{Principles for Spiritual Discernment}

This chapter isn't a comprehensive treatise about Ignatian spiritual discernment, ${ }^{13}$ rather we will discuss some key issues that are helpful for discerning in a "VUCAworld." 14 There is a strange paradox in Ignatian spirituality that is relevant to the

\footnotetext{
${ }^{11}$ This is an ontological as well as an epistemological claim. For extensive theological and philosophical arguments within a Jesuit tradition see the many works of Karl Rahner (Endean 2009).

${ }^{12}$ According to Alfred Darmanin it is less the military metaphors than the "organization as a body metaphor" which is dominant (2005, p. 10). Taking Ignatius's actual phrasings in Spiritual Exercises and his pre-conversion obsessions for the military into account, I find Darmanin's argument unconvincing.

${ }^{13}$ For a more extensive treatment of spiritual discernment, see the works of Timothy M. Gallagher (2009, 2012, 2013).

${ }^{14}$ It is also based on limited personal experience, not as a Jesuit, not even a Roman Catholic, but as an evangelical-protestant inspired by this type of frontier spirituality. In a more protestant
} 
postmodern experience of the VUCA-world. On the one hand, the Ignatian principles create an awareness that the future is not in our hands; they are intended to help a person live in the moment and deal with unpredictable events, and to survive in a volatile and uncertain environment. On the other hand, there is a commitment to reflect profoundly on one's choices and to consider all the options. Spiritual discernment is often oriented towards making choices, in particular the hard lifechanging choices. Or it can be discerning to allow the active choice to continue and to become recommitted. In the choice also lies the paradox, we can't choose just everything and some choices that have been made can't be undone. Acceptance of the unchangeable, whatever this may be, is a presupposition for discernment. ${ }^{15}$

\subsection{Humility and Telos}

Perhaps the most important rule for spiritual discernment is the conditional virtue of humility, as it is arrogance which blinds and misleads us. Ignatius suggests we start our process of discernment in the following way: "A step or two away from the place where I will make my contemplation or meditation, I will stand for the (time)length of an Our Father [prayer 1 min.]. I will raise my mind and think how God our Lord is looking at me, and other such thoughts. Then I will make an act of reverence or humility." (Sp.Ex. 75) We start with a moment of awareness (the length of time that the Lord's Prayer lasts). We experience the way in which God looks at us in a loving way, more loving than we can love ourselves. It is crucial that we don't start with self-love, but rather from the love of God bestowed on us. The whole spiritual exercise and discernment process is considered to be an exercise in humility. God blesses the poor in spirit, the beggars (Mat. 5: 3).

According to Scharmer, a leader can't advance to a higher level of performing without humility, or a selfless self. We won't touch our essential core, our emerging future Self (capital S), if we refuse to go deep down. Scharmer calls it "going through the eye of the needle." "We must learn to drop our ego and our habitual 'self' in order for the authentic Self to emerge" (Scharmer 2016, p. 42). It is interesting that Scharmer makes direct reference to Jesus' words to the rich, that it is as hard for them to enter into the Kingdom of God, as it is for a camel to go through a small gate called "the needle." The camel driver had to unload his animal before he could enter: "Likewise, at the bottom of $\mathrm{U}$ there is an inner gate that requires us to drop everything that isn't essential" (Scharmer 2016, p. 187). According to Scharmer, there are three inner voices of resistance which

\footnotetext{
vernacular, the spirituality of Dietrich Bonhoeffer has the same focus on calling and "Christ in the world." The Ignatian spirituality fits this type of engagement with society (Nullens 2011).

${ }^{15}$ According to the catholic priest Ignatius, "there are things that fall under an unchangeable choice, such as priesthood, marriage, etc." even "if the choice has not been made as it should have been" (Sp.Ex. 171). Marriage and priesthood are sacramental and therefore involve an ontological change that can't be altered. Most people nowadays will disagree with this, but it remains a fact that some things can't be changed.
} 
block the gate to the open mind: the voice of judgment, the voice of cynicism, and the voice of fear (Scharmer 2016, pp. 43, 44). Arrogance is part of the voice of cynicism, as it refuses to become vulnerable. Nevertheless, one wonders why the blocking voice of hubris isn't mentioned here, since presencing also means an absence of manipulative behavior and the creation of a connection with the beings who surround us. This intense spiritual experience is described differently by various religious traditions, for Christians it is God, Christ, and the Holy Spirit (Scharmer 2016, p. 185). In this experience, which takes place at the bottom of the $\mathrm{U}$, it is common that the personal ego is diminished and the connection with beings who surround us is increased.

The ethical challenge is serious. It is widely documented that many senior leaders, especially in the highly competitive business world, have a narcissistic tendency (Johnson 2011, p. 47) or "swollen egos" (Scharmer, p. 73). Narcissism has helped them get to the top: in those that are successful, self-centeredness is combined with charisma, high energy, and intelligence. They can be efficient and effective, but their moral compass tends to be underdeveloped. Characteristics of these types of leaders are arrogance, amorality, feelings of inferiority, an insatiable need for appreciation, hypersensitivity and anger, lack of empathy, irrationality and inflexibility, and even paranoia (Sankowsky 1995; Rosenthal and Pittinsky 2006). In a VUCA-world they may actually flourish, but often at great cost to all stakeholders in the organization. And as Craig Johnson observed, their self-centeredness blocks innovation and growth: "Ego-driven leaders ignore creative ideals and valuable data that come from outside their circle of influence" (Johnson 2011, p. 46). For this reason, the so-called "great man theory of leadership" fundamentally collides with the essence of Ignatian spirituality, which teaches one has to become small and make a conscious choice to serve (Greenleaf 2002, pp. 27, 28).

Humility is also a helpful virtue when we try to disconnect ourselves from people's opinions of us. As a disposition, it is closely related to the experience of leaving behind the focus on ourselves. The first week opens: "Man is created to praise, reverence, and serve God our Lord, and by this means to save his soul. . . Our one desire and choice should be what is more conducive to the end for which we are created" (Sp.Ex. 23). The purpose of life is God's greater glory. ${ }^{16}$ Nonbelievers understandably might have difficulty with this. At the same time, it is important for fostering our altruism that we leave our own ego behind. A retreat can start with turning in on oneself but should eventually lead to a transcendence of oneself and experience of oneself within a larger network. "This approach makes room for the integration of development built on a foundation of ego-transcendence, love, or God. It also leaves to each leader to discern, in interaction with other organization members, which organizational missions to forward (ends) and how (means)" (Rothausen 2017, p. 2).

\footnotetext{
${ }^{16}$ This reminds us of the first question of the Westminster Shorter Catechism: " 1 . What is the chief end of man? Man's chief end is to glorify God, and to enjoy him forever."
} 


\subsection{Silence, Detachment and Indifference}

Spiritual exercises are inconceivable without times of solitude, silence, and detachment. We practice being still with God, just to be in His presence, in much the same way as silent company is part of any profound relationship. We learn to be disconnected from our lower superficial self, rediscover our deepest desirers, the voice of the inner self where God speaks, then refocus, and finally reconnect with society. In a turbulent world of constant noise and stimulation, several days of silence can be an odd experience. It is in silence that we create room for encountering God in our very depths. Many managers describe their activities as "getting things done," "keeping everyone in the loop," "putting out fires," "react and navigate," "have impact," "call Mr. x and mail Mss. y" etc. Taking time for reflection and detaching oneself from daily pressures seems to be a luxury, only available to the elite. Yet those who have managerial responsibilities need this profoundly (Moberg and Calkins 2001, p. 257). Through silence one develops a receptive attitude, an openness to experiencing the beauty of nature as incarnated beauty. In short, one develops a contemplative receiving attitude towards reality instead of a manipulative or controlling attitude (Verstraeten 2014, p. 89). It is only through silence that one comes in contact with one's deeper self, one is able to listen to one's own consciousness. Finally, one develops the skill of listening, indispensable for leading an organization.

The experience of detachment is also mainly caused by the experience of silence and the minimalism of a retreat setting. As stated before, the heart of Ignatian spirituality is freedom and detachment. Humility is detachment from the agenda of the self, silence from the surrounding multitude of information. According to Ignatius, the detachment of a pilgrim on this earth yet living out of another reality, is a fundamental attitude. For discernment one needs to become detached from all kinds of desires and needs. Indeed, it is through detachment that one becomes open to new possibilities. Before making any important decision, our general spiritual state should be to "make ourselves indifferent to all created things" (Sp.Ex. 23). In this context, "indifference" has a particular meaning. It relates to the attitude of freedom and detachment. It is a mental state in which you can take sufficient distance from your own condition, views, and prejudices, and this is hard to achieve. Is absolutely everything becoming an option in your mind? Are you really free to serve God in everything? "Indifference is another way of describing spiritual freedom. It is a stance of openness to God: we look for God in any person, any situation, and any moment. Indifference means that we are free to love and serve as God desires" (Martin 2010, p. 210). In contemporary words we might call this a "zero calibration," to ensure that our "mental needle" reads zero, every option becomes possible.

Some key words in Theory-U are "open mind" and "state of fundamental freedom." For Scharmer the social technology of presencing is essentially a technology of freedom (Scharmer 2016, p. 184). We need to create a mental space for letting go of 
the old and everything that isn't essential before we can co-create the new. ${ }^{17}$ For this profound experience we need to find a sacred place of silence or deep listening. Only here do we allow the inner knowing to emerge. Through silence one feels connected with others and new creative ideas emerge (Scharmer 2016, p. 237).

\subsection{The Primacy of Emotions and Imagination}

Spiritual Exercises reflects on the moods of our soul, our longings, and feelings. "Discerning the spirits" has a broad meaning and implies affective stirrings of our heart, the experience of emotions such as anxiety, sorrow, joy, peace, or hope, as well as the thoughts related to these feelings. The purpose is to identify which emotions are from God and which are not (Gallagher 2013, loc. 365-367). Two opposite affective states are crucial: consolation and desolation. We imagine our decisions and ask ourselves what comforts or discomforts us in light of our journey through life. "I call it consolation when an interior movement is aroused in the soul, by which it is inflamed with love of its Creator and Lord, and as a consequence, can love no creature on the face of the earth for its own sake, but only in the Creator of them all ... I call consolation every increase of faith, hope, and love" (Sp.Ex. 316). "And the opposite desolation, as darkness of soul, turmoil of spirit, inclination to what is low and earthly, restlessness rising from many disturbances and temptations which lead to want of faith, want of hope, want of love. The soul is wholly slothful, tepid, sad, and separated, as it were, from its Creator and Lord" (Sp.Ex. 317). The whole reflective process is about ordering our confused desires. It is important not to make any important decisions in times of desolation, but at such times to "preserve in patience" (Sp.Ex. 321). God alone can give consolation of the soul (Sp.Ex. 330).

Ignatius speaks about three stages or modes. In the first mode, one knows exactly what choice God calls us to make, it is merely a matter of obedience (Sp.Ex. 175). In the second stage, we investigate more deeply our emotional experience of consolations and desolations (Sp.Ex. 176). The third mode is about making a rational choice by thinking through all the options and weighing the pros and cons (Sp.Ex. 176). It is when the affective is unclear that the rational takes priority. And even then, one has to come back to the affective to see whether the rational choice gives consolation. In short, the Spiritual Exercises prioritize the emotional dimension over the rational decision process (O'Sullivan 1990). The exercitant is encouraged "to probe the netherworld of non-cognizant knowledge" (Moberg and Calkins 2001, p. 265). To be clear: we are not referring to a chaos of emotions and intuitions, but to ordered

\footnotetext{
${ }^{17}$ Scharmer interacts with the famous cognitive scientist Francisco Varela who studied the process of becoming aware. For the transcript of the often-used interview https://www.presencing.org/\#I aboutus/theory-u/leadership-interview/francisco_varela
} 
affections as a basis for discernment. ${ }^{18}$ Lennick and Kiel make a case for moral intelligence in leadership. They rightfully pay a lot of attention to emotions and to reflecting on our emotions with the purpose of recognizing patterns in our responses to situations. In times of reflection one should ask: "During what experiences in my past have I felt happy, excited, hopeful, angry, sad, or fearful?" (2011, p. 170).

This leads us to another point: the ordering of our affects through imagination and creativity. In Theory-U, imagination and creativity are also treasured. Creativity, individual as well as collective creativity, is the ultimate source for all capital and value creation (Scharmer and Kaufer 2013). They offer visual practice programs as well as a presencing theater. ${ }^{19}$ In Theory-U the self, being bodily connected to others and the world around us, is the main source for creativity.

In Ignatian discernment, imagination and creativity are related to the experience of Scripture. Scripture is used as an external source for our inner ordering. A combination of meditation (reflection) and contemplation (imagining) is arrived at (Gallagher 2008). Imagination enables us to see things in a new light and can be a pathway to innovation (Verstraeten 2014, p. 86), and an important part of the Ignatian meditation exercises is picturing gospel scenes. The object of these meditation exercises is to focus on the life, passion, and resurrection of Jesus. Our imagination is not only a visual activity, but also involves feeling, smelling, tasting, and experiencing with all the senses, just as if one were there. One is creating a drama and participates in the performance. Martin gives as an example the passage of Jesus in the storm: "even here in the boat, you might imagine tasting the saltwater spray. Now that you have used your senses and 'composed the place,' you have the scene set. At this point you can just let the scene play out in your mind, with you in the picture" (Martin 2010, loc. 2510-2513). The exercise of imagination is not impulsive or random, but based on an assignment given by the spiritual director. This intense focus on Christ breaks with our tendency for self-absorption (Moberg and Calkins 2001, p. 264). Biblical stories can help us to integrate our work with our lives, or as Verstraeten formulates it: "contribute to the narrative reconfiguration of a leader" (Verstraeten 2014, p. 88). ${ }^{20}$

The power of imagination is not only used for contemplating Scripture, it is also used to imagine different circumstances and the decisions one can make. Through imagination, a person's social network comes into the picture: husband, children, friends, colleagues etc. Imaginative prayer thus has a socially constructed content (Moberg and Calkins 2001, p. 264). In leadership studies, there is an awareness of the importance of the skill of imagination and talent of telling vivid stories, for innovation as well as for creating a common vision in an organization (Liu and Noppe-Brandon 2011).

\footnotetext{
${ }^{18}$ In Christian ethics, especially within the Protestant tradition, the role of emotions and experiences has been vastly undervalued and the power of cognitive reasoning overvalued (Van den Heuvel et al. 2018).

${ }^{19}$ See for both https://www.presencing.org

${ }^{20} \mathrm{We}$ are not autonomous self-sufficient identities but are configured by the other (E. Levinas), not only concretely, but also by the otherness of the text (P. Ricoeur). Cf. Verstraeten (2014).
} 


\subsection{The Two Standards and Ethical Evaluation}

With the power of imagination in mind, one comes to the exercise of "imagining the Two Standards." Ignatius's former love of the battlefield presumably plays an important role in the imagination exercise of the two banners during the second week (Sp.Ex. 136-148). The retreatant imagines two armies, each with a flag, banner or standard. On one side we see the army of Christ, on the other the army of Satan. This conflict metaphor goes back to the conflict between Jerusalem and Babylon as we find it in the New Testament, another example of it can be found in Augustine's City of God and City of Satan. This meditation on the Two Standards refers to the battle within ourselves, between that which moves us toward God and that which moves us away from Him. That which moves us toward God is the good spirit, and that which moves us away from Him is the evil spirit. Christ the King is calling us to choose his side and leave behind the riches and honors calling from the other side. Discernment is the art of distinguishing between those two forces. It requires acquaintance with the voice of Christ, as well as insight in the subtle strategies and seductions of evil. ${ }^{21}$ Jesus is calling us to choose the more demanding path, the one asking for imitatio Christi, which involves suffering, poverty, humility, service and contempt. Ignatius describes evil as "Lucifer, the deadly enemy of our human nature" (Sp.Ex. 136). In contrast, according to him, Jesus empowers us to embrace our humanity in all of its beautiful complexity and transforms us according to his image, into loving and serving people. In present-day language, we might investigate our desires and ask ourselves what is humane or inhumane about them. In this part of the exercise, the moral dimension of discernment is at the forefront. We are confronted with our own fixations on power, possessions, esteem, etc.

The investigation of our desires and decisions is particularly important in business and leadership ethics. In dealing with a sense of purpose and the discernment between good and evil we come to the very heart of authentic leadership. This part of discernment is similar to what George calls "discovering your true North." It is the internal compass, based on your deeper self and life story, which leads us on in a tumultuous world (George et al. 2015).

As the ethicist Craig Johnson states: all leadership has a dark and a light side. The question is: do we cast light or shadow? (Johnson 2011). In order to answer this question, we must start with a reflective practice which goes beyond following a set of rules, but which is about mastering our inner drives and attachments. The answer thus lies in well-developed basic trust (Verstraeten 2014, pp. 92, 93). To be engaged in this type of meditation also means that one consciously scrutinizes the defining moments of our past practices. Did we really act in accordance to what we believe is good and in line with our moral compass and goals? The exercise of the Two Standards is similar to what we now refer to as reflecting on the big picture and reframing the situation (Lennick and Kiel 2011, pp. 174, 175).

\footnotetext{
${ }^{21}$ Compare C.S. Lewis' famous book The Screwtape Letters (1942), letters from Demon Screwtape to his young nephew Wormwood, about tempting a Christian (the patient).
} 
Theory-U has developed the big picture well. In fact, the theory is entirely about a change from the small to the big picture, our global crisis. With our industries and markets we are collectively creating results that nobody really wants. Our crisis can only be solved if we start thinking from the heart instead of only from the head. This means a shift from an ego-system awareness to an eco-system awareness, a focus on our oikos or the whole house we all live in (Scharmer and Kaufer 2013, p. 2). Discernment requires the ability to let go of the past and lean into the future that wants to emerge through us, and an openness to let it come to us. The metaphor of the iceberg is used to describe the relationship between spiritual awareness and the disruption in our world. In each layer, from surface to depth, there are blind spots which need to be addressed. On the surface, the level of symptoms, we are confronted with the visible behaviors. They appear in three divides: ecological divide (self and nature), social divide (rich and poor) and spiritual-cultural divide (self and Self). This last one manifests itself in an overstressed society with increasing cases of burnout and depression. Beyond the surface, that which does not appear, we find the wrong structures. Without going into details of Scharmer and Kaufer's diagnosis of our world, the main point is that one finally ends up in the deeper source, the inner place from which we operate.

\subsection{Journaling and Mentoring}

Journaling is an important spiritual and reflective practice. Ignatius made notes of his observations regarding his inner life. He registered what gave him consolation and what led to desolation and, with the help of his notes, tried to discern patterns in his behavior. He also recopied his notebook regularly. A journal is strictly personal, it is our spiritual memory and a reminder of our vocation, images, prayers and struggling. In our notes, we also connect our bible readings and prayers with events in our daily life, however small. In this way the journaling has an integrating function. "A spiritual notebook or journal can be an anchor to remind the leader of her or his vocation and higher purpose. Revisiting, rereading, or even rewriting these notes on a regular basis could center the leader in the spiritual aspects of her or his leadership" (Rothausen 2017, p. 5).

Even though the journal is personal, it can be used for a conversation with a mentor or spiritual director. Ignatian reflection is not a strictly individual endeavor, it is a guided reflection. The role of the director is one of careful guidance in the process of discernment and to discriminate internal movements. The spiritual director daily provides the exercitant with material for about four hours of meditation; the next day they review how it went. The director helps to interpret the experiences of the exercitant and proposes new material for the following day. But we keep in mind that God deals directly with the exercitant and so the director must be very careful not to interfere in this process. This type of guidance is an immense responsibility and requires a special skill. Moberg and Calkins express a caution: "Guided reflection ... is not intended to be the tool of someone looking for another technique to 
shoehorn into his or her consulting practice. Too much damage has been done by charlatans to allow this process to fall into the wrong hands" (Moberg and Calkins 2001, p. 266). An important principle is that discernment is very personal as well as relational; as we talk things through with our director, our ideas and feeling become clearer.

\section{Conclusion}

I opened this chapter with a quest for authentic leadership in a VUCA-world. Authentic leadership requires an inner compass to give us direction in making decisions. Authenticity originally means to be true to oneself. It is within this internal coherence that we evaluate options and discern. Psychologists, such as Carl Rogers and Abraham Maslow, have developed this humanistic psychology of the selfactualized personality. These models incorporate strong moral convictions and require that we are in tune with them, that we are authentic (Avolio and Gardner 2005). This has been picked up later, in a more empirical way, by positive psychologists and the importance of positive psychological capital in organizations (Luthans et al. 2007). In Theory-U, there is the inner divide between the self and the Self (capital S), the person we can become. We must drop our habitual self in order for the authentic Self to emerge (Scharmer 2016, p. 42). Successful leadership depends on the quality of attention and intention that the leader brings to any situation. Of great contribution is the way in which Theory-U creates a bridge between the inner space within ourselves, and the global ethical challenges we are faced with. Discernment spirituality, in this case characterized by presencing an emerging future, becomes a tool for social development. It is a shift from an ego-system awareness that cares about the wellbeing of oneself, to an eco-system awareness that cares about the wellbeing of all, overcoming the ecological divide, the social divide and spiritual cultural divide. This broad and yet profound framing gives us direction for discernment.

However, one may wonder if the self is able to let a better Self emerge without some kind of resourcing from a faith tradition or at least a larger narrative which confronts the self. Maybe this is Otto Scharmer's own blind spot? Are we able to overcome superficial judgments, cynicism, fear, and egocentrism by our own internal power? The answer from the Ignatian tradition is that we can't. The experience of calling and purpose presuppose a transcendental act which lifts us up beyond our own capacities and helps us overcome our selfish ego. Theologically speaking, or from the perspective of a Christian faith-narrative, the emerging Self is a restoration of the imago Dei, a new person able to connect and to love as Christ did. ${ }^{22}$ This is why Ignatius's method of discernment invites

\footnotetext{
${ }^{22}$ The intimate unity between the experience of the self and God we find in the work of the Jesuit, Karl Rahner. We can't experience the one without the other and anthropology starts and ends with Christology (see especially Volume 13 of Theological Investigations). More practically, this
} 
us first of all to pause and become aware of the God who loves me. Secondly to face our own weaknesses, faults, and mistakes as they cast a shadow on the present and future. Ignatius doesn't avoid the feelings of shame, but faces them head on and from there moves forward to forgiveness and healing. The source of healing is not coming from the self, but from a trust in a loving God speaking to the self. Trusting on the self is a mistake as is only seeing our own weaknesses can be paralyzing. I concur with Theresa Rothausen that these practices of confronting are crucial for all leader development (Rothausen 2017, p. 12). Discerning as an authentic person means on the one hand an experience of our failures, and on the other hand the experience of being loved and of intense gratitude. Without this real "eye of the needle," the confession of selfishness and the continuous healing of it, spiritual discernment leading to moral change for the common good, might remain an illusion.

\section{References}

\section{Source Texts}

Ignatius of Loyola (1951) The spiritual exercises of St. Ignatius: based on studies in the language of the autograph. English edition: Louis J Puhl (1951), available at http://spex.ignatianspirituality. com/SpiritualExercises/Puhl\#pre01. Accessed 15 Jan 2018

Ignatius of Loyola, Munitiz JA, Endean P (eds) (1997) Personal writings. Penguin, London

Ignatius of Loyola, Palmer ME, Padberg JW, McCarthy JL (2006) Letters and instructions. Institute of Jesuit Sources, Saint Louis, MO

\section{Other Sources}

Avolio BJ, Gardner WL (2005) Authentic leadership development: Getting to the root of positive forms of leadership. Leadership Q 16(3):315-338

Avolio BJ, Luthans F (2005) The high impact leader: authentic, resilient leadership that gets results and sustains growth. McGraw Hill, New York

Bennett N, Lemoine GJ (2014) What VUCA really means for you. Harv Bus Rev, 1 Jan 2014. https://hbr.org/2014/01/what-vuca-really-means-for-you. Accessed 18 Jan 2018

Bouckaert L (2017) Spiritual discernment as a method of judgment. In: Nandram SS, Bindlish PK (eds) Managing self through integrative self-management: how to cope with volatility, uncertainty, complexity and ambiguity in organizational behavior. Springer, Dordrecht, pp 15-25

Caraman P (1990) Ignatius Loyola: a biography of the founder of the Jesuits. Collins; Harper \& Row, London

Chiesa A, Serretti A (2009) Mindfulness-based stress reduction for stress management in healthy people: a review and meta-analysis. J Altern Complement Med 15(5):593-600. https://doi.org/10.1089/acm.2008.0495

therapeutic view on salvation as restoration of the image of God is characteristic of the Wesleyan tradition, as it is closely related to the Greek Church Fathers (Maddox 1994). 
Covey SR (2014) The 8th habit: from effectiveness to greatness. Simon \& Schuster, London

Darmanin A (2005) Ignatian spirituality and leadership in organizations today. Rev Ignatian Spirituality 36(2):1-14

Dhiman S (2017) Holistic leadership: a new paradigm for today's leaders. Springer, Dordrecht

Endean P (2009) Karl Rahner and Ignatian spirituality. Oxford University Press, Oxford

Fry LW (2003) Toward a theory of spiritual leadership. Leadership Q 14(6):693-727. https://doi. org/10.1016/j.leaqua.2003.09.001

Fry LW, Nisiewicz MS (2013) Maximizing the triple bottom line through spiritual leadership. Stanford Business Books, Stanford, CA

Gallagher TM (2008) Meditation and contemplation: an Ignatian guide to praying with scripture. Crossroad, New York

Gallagher TM (2009) Discerning the will of God: an Ignatian guide to Christian decision making. Crossroad, Chicago, IL

Gallagher TM (2012) Spiritual consolation: an Ignatian guide for greater discernment. Independent Pub Gr, Kindle

Gallagher TM (2013) Discernment of spirits: a reader's guide. Crossroad, New York

George B, Craig N, Snook SA (2015) The discover your true north fieldbook: a personal guide to finding your authentic leadership. Wiley \& Sons, Hoboken, NJ

Giacalone RA, Jurkiewicz CL (2015) Handbook of workplace spirituality and organizational performance. Routledge, New York

Goleman D (2014) Emotional intelligence. Bloomsbury, London

Greenleaf RK (2002) Servant leadership: a journey into the nature of legitimate power and greatness. Paulist, New York

Hannah ST, Avolio BJ, Walumbwa FO (2011) Relationships between authentic leadership, moral courage, and ethical and pro-social behaviors. Bus Ethics Q 21(4):555-578

Heiding SF (2012) Ignatian spirituality at ecclesial frontiers. Dissertation, Oxford University

Heuvel SC van den, Nullens P, Roothaan ACM (2018) Theological ethics and moral value phenomena: the experience of values. Routledge, New York

Hinson EG (2007) Ignatian and puritan prayer: surprising similarities; a comparison of Ignatius Loyola and Richard Baxter on meditation. Merton Annu 20:79-92

Holder A (2005) The Blackwell companion to Christian spirituality. Blackwell, Malden, MA

Inglehart R (1997) Modernization and postmodernization: cultural, economic, and political change in 43 societies. Princeton University Press, Princeton, NJ

Inglehart R, Welzel C (2005) Modernization, cultural change, and democracy: the human development sequence. Cambridge University Press, Cambridge, MA

Johnson C (2011) Meeting the ethical challenges of leadership: casting light or shadow. Sage, London

Lafontaine R (2011) Ignace de Loyola et Martin Luther: vie spirituelle et théologie. Nouvelle rev théologique, Tome 133(1):45-64. https://doi.org/10.3917/nrt.331.0045

Lennick D, Kiel F (2011) Moral intelligence 2.0: enhancing business performance and leadership success in turbulent times. Prentice Hall, Upper Saddle River, NJ

Liu E, Noppe-Brandon S (2011) Imagination first: unlocking the power of possibility. Jossey-Bass, San Francisco, CA

Luthans F, Youssef CM, Avolio BJ (2007) Psychological capital: developing the human competitive edge. Oxford University Press, Oxford

Maddox RL (1994) Responsible grace: John Wesley's practical theology. Kingswood Books, Nashville

Martin J (2010) The Jesuit guide to (almost) everything: a spirituality for real life. HarperCollins, New York, Kindle

Maryks RA (2014) A companion to Ignatius of Loyola: life, writings, spirituality, influence. Brill, Leiden

Meissner W (1994) Ignatius of Loyola: the psychology of a saint. Yale University Press, New Haven, CT 
Moberg DJ, Calkins M (2001) Reflection in business ethics: insights from St. Ignatius' spiritual exercises. J Bus Ethics 33(3):257-270. https://doi.org/10.1023/A:1017574904755

Neal J (ed) (2012) Handbook of faith and spirituality in the workplace: emerging research and practice. Springer, New York

Northouse PG (2016) Leadership: theory and practice. Sage, Los Angeles, CA

Nullens P (2011) Dietrich Bonhoeffer: a third way of Christian social engagement. Eur J Theol 20 (1):60-69

O'Brien KF (2011) The Ignatian adventure: experiencing the spiritual exercises of Saint Ignatius in daily life. Loyola Press, Chicago, IL

O'Sullivan MJ (1990) Trust your feelings, but use your head: discernment and the psychology of decision making. Semin Jesuit Spirituality, St. Louis, MO

Otto R (1959) The idea of the holy. Penguin, Harmondsworth

Pargament KI, Mahoney A (2011) Spirituality: the search of the sacred. In: Lopez SJ, Snyder CR (eds) Oxford handbook of positive psychology. Oxford University Press, New York, pp $611-620$

Quick CJ, Gavin JH, Cooper CL, Quick JD (2000) Executive health: building strength, managing risks. Acad Manag Perspect 14(2):34-44

Reave L (2005) Spiritual values and practices related to leadership effectiveness. Leadership Q 16 (5):655-687. https://doi.org/10.1016/j.leaqua.2005.07.003

Richter F (1955) Martin Luther und Ignatius von Loyola: Repräsentanten zweier Geisteswelten. Schloz, Stuttgart-Degerloch

Rosenthal SA, Pittinsky TL (2006) Narcissistic leadership. Leadership Q 17(6):617-633

Rothausen TJ (2017) Integrating leadership development with Ignatian spirituality: a model for designing a spiritual leader development practice. J Bus Ethics 145(4):811-829

Sankowsky D (1995) The charismatic leader as narcissist: understanding the abuse of power. Organ Dyn 23(4):57-71

Scharmer CO (2016) Theory U: leading from the future as it emerges: the social technology of presencing. Berrett-Koehler, San Francisco, CA

Scharmer CO, Kaufer K (2013) Leading from the emerging future: from ego-system to eco-system economies. Berrett-Koehler, San Francisco, CA

Vaughan F (2002) What is spiritual intelligence? J Humanist Psychol 42(2):16-33

Verstraeten J (2014) Spirituality as source of inspired, authentic and innovative leadership. In: Nullens P, Barentsen J (eds) Leadership, innovation and spirituality. Christian perspectives on leadership and social ethics. Peeters, Leuven, pp 49-58

Waaijman K (2007) Spirituality—a multifaceted phenomenon: interdisciplinary explorations. Stud Spirituality 17:1-113. https://doi.org/10.2143/SIS.17.0.2024643

Wakefield JL, Ignatius (2006) Sacred listening: discovering the spiritual exercises of Ignatius Loyola. Baker, Grand Rapids, MI

Warner L (2010) Journey with Jesus. IVP, Downers Grove, IL

Wigglesworth C (2014) SQ21: the twenty-one skills of spiritual intelligence. Select, New York

Zohar D, Marshall IN (2001) SQ: the ultimate intelligence. Bloomsbury, London 
Patrick Nullens (Ph.D.) is Full Professor of Systematic Theology at the Evangelische Theologische Faculteit, Leuven (Belgium). He is cofounder of Institute of Leadership and Social Ethics and member of its steering committee. Furthermore, he is Extraordinary Professor of Theology at North-West University, South Africa. During his career, he has been mostly involved in different leadership roles. Innovation and spirituality are two core values in his personal journey. $\mathrm{He}$ is convinced of the importance of theology in practice. Therefore, he regularly preaches in both the Netherlands and Belgium. He publishes regularly in the field of theology, ethics and leadership.

Open Access This chapter is licensed under the terms of the Creative Commons Attribution 4.0 International License (http://creativecommons.org/licenses/by/4.0/), which permits use, sharing, adaptation, distribution and reproduction in any medium or format, as long as you give appropriate credit to the original author(s) and the source, provide a link to the Creative Commons licence and indicate if changes were made.

The images or other third party material in this chapter are included in the chapter's Creative Commons licence, unless indicated otherwise in a credit line to the material. If material is not included in the chapter's Creative Commons licence and your intended use is not permitted by statutory regulation or exceeds the permitted use, you will need to obtain permission directly from the copyright holder. 